\title{
When volcanic eruptions and shallow- level granites are siblings: the case of the Takidani magmatic complex
}

\author{
FEDERICO FARINA ${ }^{1}$, EVA HARTUNG ${ }^{2}$, GREGOR \\ WEBER $^{3}$, PROF. DANIELA RUBATTO ${ }^{4,5}$ AND LUCA \\ CARICCHI $^{6}$ \\ ${ }^{1}$ Università degli Studi di Milano \\ ${ }^{2}$ University of Liverpool \\ ${ }^{3}$ University of Oxford \\ ${ }^{4}$ University of Lausanne \\ ${ }^{5}$ University of Bern, Institute of Geological Sciences \\ ${ }^{6}$ University of Geneva \\ Presenting Author: federico.farina@unimi.it
}

The Takidani pluton (Central Japan Alps) is a vertically zoned intrusion with granodiorite to granite composition and one of the youngest exhumed intrusions on Earth (1.1 - 1.6 Ma). It was intruded at the base of a Pleistocene caldera fill sequence of tuffs and lavas (ca. 2.4 Ma) and is closely associated with two large eruptions, the Nyukawa dacite and the Chayano-Ebisutoge rhyolite.

Petrographic as well as major, trace element and isotope evidence indicate that the three uppermost units of the pluton and the Nyukawa eruption are co-genetic. In particular, in-situ zircon $\delta^{18} \mathrm{O}$ data range between 6.0 and $7.5 \%$, with no significant difference between the pluton and the Nyukawa dacite. Highprecision $\mathrm{U}-\mathrm{Pb}$ zircon dating by CA-ID-TIMS shows that the dacite is older than the pluton, with a ${ }^{206} \mathrm{~Pb} /{ }^{238} \mathrm{U}$ zircon age of $1.706 \pm 0.087 \mathrm{Ma}$. The three dated units of the pluton have variable but overlapping zircon ages comprises between ca. 1.2 and 1.5 Ma and each unit exhibits an age spread of 100-300 kyr. In-situ U-Pb dating by SIMS confirmed and slightly expanded the age variability observed in CA-ID-TIMS (300-350 kyr), supporting the lack of any systematic age difference between the units.

Unless unrealistically high thermal gradients or extreme magma fluxes are considered, the integration of $\mathrm{U}-\mathrm{Pb}$ dates and thermal modelling shows unequivocally that zircon crystallized at depth and were subsequently recycled and juxtaposed during ascent and emplacement of the magmas at shallow level. This conclusion is in agreement with the Al-in-hornblende geobarometer indicating that amphibole formed at pressures between 0.25-0.6 GPa, in stark contrast with field evidence supporting emplacement at pressures $<0.15 \mathrm{GPa}$. Our data suggest that the shallow level Takidani pluton does not represent the fossil magma plumbing system that fed the large calderaforming volcanic eruptions in Central Japan. Instead, the Nyukawa dacite and the Takidani pluton are both sourced at different times from the same mush-dominated reservoir in the middle crust. The first magmas that were extracted from the mush erupted, while the following episodes of magma segregation led to the incremental assembly of the Takidani pluton. 